\title{
Mild Chronic Inflammation
}

National Cancer Institute

\section{Source}

National Cancer Institute. Mild Chronic Inflammation. NCI Thesaurus. Code C82907.

A chronic inflammatory process characterized by the accumulation of a small number of lymphocytes and plasma cells. 